\title{
PERANAN VISA ON ARRIVAL (VOA) BAGI ORANG ASING YANG DATANG KE INDONESIA
}

\author{
Luh Putu Sudini*
}

\section{Abstrak}

This article does elaboration regarding the RI government policy on allied entrance into national territory during their visit. The visa on arrival policy is granted in the immigration (Custom) check points or another entry points which has been declared under Decree of the Ministry of law and Human Right of the RI No. M-04 .IZ.01.10 year 2003, regarding Visa on Arrival (VOA). Then after for allied who would visit to Indonesia can seek their VOA at Indonesia's harbour or airport where their arrival. It becomes simply ways to get visa for their entry to Indonesia for their various tourism, business activity or just transit needs. Shortly, under that policy either allied or Indonesian goverment would get advantages merely for easy beraucracy and convenience entry with also devisa earning as primary consideration.

Kata kunci: Visa On Arrival (VOA), orang asing, Indonesia

\section{Pendahuluan}

Dalam era globalisasi perkembangan dunia internasional semakin maju, baik secara Publik maupun privat/perdata. Dalam pergaulan dunia inernasional Negara-negara di dunia hidup saling berdampingan antara yang satu dengan masyarakat dunia internasional lain seiring ilmu pengetahuan dengan tekhnologi yang semakin canggih sehingga sarana serta prasarana dalam bidang transportasi dan komunikasi menjadi semakin maju sehingga perlintasan arus lalu lintas masyarakat internasional antar negara semakin meningkat. Peningkatan jumlah arus masyarakat internasional mempunyai pengaruh dalam melatar belakangi pertumbuhan perekonomian, situasi politik dan sosial budaya semakin kompleks dan majemuknya suatu bangsa dengan meningkatnya arus lalulintas masyarakat internasional. Berbagai hal dan kepentingan melatarbelakangi hubungan internasional sehingga terjadi perpindahan manusia maupun pergerakan arus manusia yang melakukan

- Penulis adalah Dosen Tetap Fakultas Hukum Universitas Warmadewa Denpasar Bali. Dan saat ini sebagai mahasiswa Program Doktor (S3) Ilmu Hukum di Univ.Brawijaya Malang. 
lintas antar wilayah negara yang dikenal dengan istilah lalu-lintas masyarakat internasional.

Realisasi dari kerjasama ekonomi mendorong arus modal, barang dan jasa dalam bentuk investasi domestik, regional maupun internasional sehingga pertumbuhan industri menciptakan lapangan kerja serta meningkatkan sumberdaya manusia sehingga menghasilkan tekhnologi baru serta peningkatan penanaman investasi dan peningkatan aktivitas perdagangan yang akhirnya mendorong mobilitas manusia semakin meningkat. Setiap Negara mempunyai hukum maupun aturan dalam menentukan kebijakan maupun menentukan hukum dalam negara itu sendiri, baik kebijakan atau hukum yang mengatur keluar/Ekstern (terhadap dunia internasional maupun kerjasama bilateral maupun multilateral) maupun yang berlaku kedalam/Intern dalam bidang Publik maupun Privat/Perdata. Seperti contoh: Hukum Internasional ketentuan Konvensi Hukum Laut 1982 yang diratifikasi Pemerintah Indonesia melalui UU No.17 Tahun 1985 dan General Agreement of Tariffs and Trade (GATT) yang diratifikasi dengan UU No. 7 Tahun 1994.

Dalam hal pengamanan negara, Imigrasi mempunyai peranan yang signifikan dalam menjaga pintu gerbang Negara Indonesia khususnya dalam mengendalikan arus lalulintas orang berdasarkan pada kebijakan pemerintah.

Menurut Keputusan Menteri Hukum \& Hak Azasi Manusia RI, No. M.04-PR.07.10 Tahun 2001 Tentang Organisasi Dan Tata Kerja menyebutkan bahwa tugas pokok Direktorat Jenderal Imigrasi adalah melaksanakan sebagian tugas Departemen Kehakiman dan Hak Asasi Manusia Republik Indonesia di bidang keimigrasian sesuai dengan kebijakan yang ditetapkan oleh Menteri dan berdasarkan peraturan perundangundangan berlaku.

Sesuai dengan perkembangan Tri Fungsi Imigrasi, yakni sebagai Pelayan Masyarakat, Penegakan Hukum dan Keamanan Negara yang dalam pelaksanaannya harus berjalan dengan selaras, serasi dan seimbang baik dalam hal kegiatan tekhnis maupun dalam administrasi utamanya pada kebijakan Intitusi Imigrasi dalam pemberian $V O A$ bagi orang asing, yang datang ke Indonesia, dapat sebagai wisatawan atau dapat juga berkaitan dengan pembicaraan kegiatan bisnis.

Mengingat salah satu peran dan fungsi Imigrasi adalah sebagai fasilitator pembangunan ekonomi, dengan adanya Visa On Arrival (VOA) memberi kemudahan bagi orang asing yang masuk ke Indonesia, maka pada kesempatan ini penulis membuat permasalahan: Bagaimana peranan Visa On Arrival (VOA) bagi orang asing yang datang ke Indonesia? 
Selanjutnya, pembahasan dipergunakan metode penelitian dengan pendekatan secara normatif-empiris. ${ }^{.}$Artinya pendekatan melalui normanorma atau peraturan perundang-undangan, seperti UU No 9 tahun 1992 mengenai Keimigrasian dikaitkan dengan permasalahan yang dibahas, dengan sumber bahan hukum yang diperoleh melalui penelitian kepustakaan (library research), dan didukung oleh bahan- bahan hukum yang diperoleh melalui data lapangan (field research). Kemudian dianalisis secara kualitatif dan dituangkan dalam bentuk deskriptif.

\section{Pembahasan}

\section{A. Pengertian Dan Dasar Hukum VOA Serta Orang Asing Di Indonesia}

Perkembangan dunia yang semakin maju dalam era globalisasi saat ini, serta kemajuan tekhnologi dan sumber daya manusia yang semakin pesat dan pula berkembangnya sarana dan prasarana dalam bidang transportasi dan komunikasi sehingga meyebabkan semakin meningkatnya arus lalu lintas masyarakat internasional dengan melatar belakangi bahwa dengan faktor perekonomian, sosial budaya, politik dan pergaulan dunia internasional dimana hidup saling berdampingan sebagai suatu komunitas masyarakat Internasional.

Menurut KepMenKeh. RI No. M-04.IZ.01.10 Tahun 2003 Tanggal 31 Desember 2003 tentang VOA atau Visa Kunjungan Saat Kedatangan menyebutkan bahwa Visa Kunjungan Saat Kedatangan atau dalam bahasa internasional dikenal dengan istilah Visa On Arrival (VOA), merupakan kebijakan pemerintah dalam hal perijinan keimigrasian yakni hal ihwal lalu lintas masuk dan keluar wilayah Negara Republik Indonesia dan pengawasan orang asing di wilayah Negara Republik Indonesia. Oleh sebab itu pemerintah melalui Instansi Imigrasi memberikan fasilitas berupa kemudahan bagi orang asing yang akan masuk ke wilayah Negara Republik Indonesia dengan berupa kemudahan pemberian visa kunjungan saat kedatangan, yaitu visa kunjungan saat kedatangan dapat diberikan kepada orang asing warga negara atau wilayah tertentu yang bermaksud mengadakan kunjungan ke Indonesia dalam rangka wisata, kunjungan ke Indonesia dalam rangka wisata, kunjungan sosial budaya, kunjungan usaha atau

\footnotetext{
${ }^{1}$ Ronny Hanitijo Soemitro, "Metodologi Penelitian Hukum", Cet. Pertama, (Jakarta: Ghalia Indonesia, 1983), hal. 12.
} 
tugas pemerintahan dengan mempertimbangkan asas manfaat, saling menguntungkan dan tidak menimbulkan gangguan keamanan.

Dengan demikian Visa Kunjungan Saat Kedatangan/Visa On Arrival (VOA) sebagai ijin tertulis, merupakan kemudahan Imigrasi yang dapat diberikan kepada orang asing yang datang ke Indonesia. Oleh karena $V O A$ dapat diberikan di pelabuhan udara atau pelabuhan laut tertentu, pada saat orang asing tiba di Indonesia. ${ }^{2}$ Visa Kunjungan saat Kedatangan (VOA) merupakan Visa atau ijin tertulis yang diberikan oleh pajabat Imigrasi di tempat pemeriksaan pihak Imigrasi pada saat kedatangan orang asing warga Negara tertentu yang bermaksud mengadakan kunjungan atau perjalanan wisata, dll ke Indonesia yang tidak mendapat fasilitas Bebas Visa Kunjungan Singkat $(B V K S)$.

Sedangkan dokumen lain yang juga harus dipenuhi oleh orang asing atau warganegara asing yang melakukan kunjungan atau datang ke Indonesia adalah berupa Paspor. Secara harfiah Paspor artinya melewati (pintu masuk) pelabuhan, sehingga Paspor adalah past atau ijin melewati pelabuhan atau pintu masuk yang berasal dari kata pass yaitu melewati dan port yaitu pelabuhan atau pintu masuk.

Dalam pergaulan komunitas internasional, perlu dipahami pula bahwa manusia merupakan bagian sebagai komunitas, namun harus dipahami pula bahwa negara tempat manusia sebagai tempat bernaung juga sebagai komunitas internasional, sehingga makna internasional tercermin sebagai keragaman terhadap negara-negara lain dalam suatu tujuan.

Ciri suatu Negara terletak pada manusia maupun pada masyarakat yang menjadi sebagai jati diri masyarakat dan menjadi warga negara tersebut. Dalam suatu Negara khususnya Indonesia yang terdiri atas warga negara Indonesia serta warga negara asing; yakni orang maupun warga Negara asing yang datang ke Indonesia berdasarkan keperluannya, yakni dalam rangka kunjungan, wisata, dan transit/singgah ataupun untuk tinggal sementara di Indonesia.

Menurut UU No.9 tahun 1992 tentang Keimigrasian, Pasal 1 Ayat (6) orang asing yaitu, orang bukan Warga Negara Indonesia, sedangakan UU No.62 tahun 1958 Yo.UU No. 12 Tahun 2006 tentang Kewarganegaraan, menyebutkan orang asing adalah: "Barangsiapa bukan Warga Negara Republik Indonesia".

2 Imam M. Santoso, "Perspektif Imigrasi Dalam Pembangunan Ekonomi Dan Ketahanan Nasional”, (Jakarta: Universitas Indonesia, 2004), hal. 216. 
Mengingat salah satu peran imigrasi adalah sebagai fasilitator pembangunan ekonomi, dalam hal ini diwujudkan dengan memberikan fasilitas berupa kemudahan kepada orang asing yang akan masuk ke wilayah Indonesia dalam hal pemberian ijin masuk serta keluar, ijin masuk kembali (re-entry permit), ijin masuk beberapa kali perjalanan (multiple re-entry permit), serta hal periijinan lainnya baik dalam hal ijin tinggal, singgah kunjungan, usaha dan hal lainnya.

Setiap orang asing yang akan masuk kedalam suatu wilayah kedaulatan negara harus memiliki Visa, sebagai ijin tertulis yang diberikan oleh pajabat yang berwenang di kedutaan Indonesia di luar Negeri. Menurut Peraturan Pemerintah No. 32 tahun 1994, Pasal 1 tentang Visa, Izin Masuk, dan Izin Keimigrasian; Visa dapat digologkan dalam beberapa jenis yaitu:

1. Visa Diplomatik;

2. Visa Dinas;

3. Visa Singgah;

4. Visa Kunjungan;

5. Visa Tinggal Terbatas.

Visa diplomatik dan Visa Dinas adalah Visa yang diatur dan dikeluarkan oleh Menteri Luar Negeri dan diberikan kepada mereka yang memegang paspor diplomatik dan paspor dinas.

Jenis Visa Singgah, Visa Kunjungan dan Visa Tinggal Terbatas merupakan Visa, yang diatur dan dikeluarkan oleh Menteri Hukum dan HAM melalui imigrasi. Visa Singgah, Visa Kunjungan, Visa Tinggal Terbatas diberikan kepada pemegang paspor biasa. Dalam hal tertentu seorang pemegang paspor diplomatik atau paspor dinas dapat diberikan visa singgah visa kunjungan, visa tinggal terbatas jika maksud kedatangannya ke Indonesia tidak bersifat diplomatik atau dinas.

\section{Jenis Visa dan Peruntukkannya}

1. Visa Singgah; bagi mereka yang bermaksud singgah di Indonesia untuk meneruskan perjalanan ke negara lain atau kembali ke negara asal.

2. Visa Kunjungan; bagi mereka yang bermaksud melakukan kunjungan dalam rangka tugas pemerintahan, pariwisata, kegiatan sosial budaya dan usaha bukan bekarja

3. Visa Tinggal Terbatas bagi mereka yang bermaksud untuk:

a. Menanamkan modal

b. Bekerja 
c. Melaksanakan tugas sebagai rohaniawan

d. Mengikuti pendidikan dan latihan atau melakukan penelitian ilmiah

e. Menggabungkan diri dengan suami dan atau orang tua bagi istri dan atau anak sah dari seorang warga Negara Indonesia

f. Menggabungkan diri dengan suami dan atau orang tua bagi istri dan anak-anak dibawah umur dari orang asing

g. Repatriasi

Berdasarkan Ketentuan Undang-undang Keimigrasian No 9 tahun 1992 Pasal 7, pihak-pihak yang dikecualikan dari kewajiban memiliki visa:

1. Orang asing warga negara dari negara yang berdasarkan Keputusan Presiden tidak diwajibkan memiliki visa

2. Orang asing yang memiliki ijin masuk kembali seperti REP (ReEntry Permit) dan MREP (Multiple Re-Entry Permit), hanya bagi pemegang Kartu Ijin Tinggal Terbatas (KITAS) dan Kartu Ijin Tinggal Tetap (KITAP)

3. Kapten, nahkoda, awak yang bertugas pada alat angkut yang berlabuh di pelabuhan atau bandara di Indonesia

4. Penumpang transit di pelabuhan atau bandara di Indonesia, sepanjang tidak keluar dari tempat pemariksaan imigrasi

Oleh karena itu dikeluarkan peraturan yang mengatur orang asing dari negara-negara tertentu diberi kemudahan untuk masuk ke Indonesia tanpa harus memiliki Visa, kebijakan ini dikenal dengan Bebas Visa Kunjungan Singkat (BVKS), bertujuan untuk memperlancar arus kunjungan orang asing yang sasarannya adalah meningkatkan arus kunjungan orang asing masuk/dating ke Indonesia guna mendorong pembangunan ekonomi, imigrasi sebagai fasilitator ekonomi.

Mereka yang termasuk dalam kategori Pasal 7 huruf a UU No 9 tahun 1992 yaitu orang asing warga negara dari negara yang berdasarkan Keputusan Presiden Republik Indoenesia merupakan suatu kebijakan yang diberikan oleh pemerintah dalam hal ini melalui imigrasi memberikan kemudahan kepada warga negara tertentu untuk masuk ke Indonesia tanpa harus memiliki visa.

Perubahan ini didasarkan pada asas manfaat \&resiprocal, kebijakan diberikan kepada negara yang secara resiprocal juga menerapkan kebijakan yang sama terhadap Indonesia. sedangkan bagi negara-negara yang tidak termasuk dalam kebijakan Bebas Visa Kunjungan Singkat (BVKS) diberikan kemudahan keimigrasian 
lainnya, yaitu Visa Kunjungan Saat Kedatangan IVisa On Arrival(VOA) yang diberikan di Bandar udara dan pelabuhan laut, sesaat setelah mereka tiba di wilayah indonesia.

Dalam memperhatikan kebijakan Visa Kunjungan Saat Kedatangan/VOA, pemberian VOA memperhatikan kepentingan negara, dimana hanya diberikan kepada negara yang benar-benar menguntungkan dan memberikan asas manfaat bagi pembangunan Indonesia, sesuai dengan asas manfaat dan resiprocal antara kedua negara dimana kebijakan antara keduanya saling menguntungkan.

Berkaitan dengan pemberian $V O A$ oleh Indonesia kepada orang asing, dalam hal ini tampak institusi imigrasi disamping memiliki trifungsi imigrasi (selective policy, security policy dan prosperity policy) juga berfungasi sebagai fasilitator pembangunan ekonomi, beperan untuk memfasilitasi pelayanan publik dengan memberikan ijin masuk kepada pelaku ekonomi mancanegara dan mengadakan perjalanan untuk menjajaki peluang investasi, membangun kontak bisnis dengan pelaku ekonomi nasional dalam rangka memberikan layanan jasa dan pemasaran lintas negara termasuk sebagai bagian dari sistem pendukung sektor pariwisata.

Menurut Kepmen Keh RI No M-04.IZ.01.10 Th 2003 Tanggal 31 Desember 2003 Tentang Visa Kunjungan Saat Kedatangan/ VOA menyebutkan Visa Kunjungan saat Kedatangan (VOA) merupakan Visa yang diberikan kepada orang asing dari negara-negara yang bukan merupakan Subyek Bebas Visa Kunjungan Singkat (SBVKS), tetapi berdasarkan kebijakan pemerintah Indonesia maka negaranegara tersebut tidak lagi menjadi Subyek Bebas Visa Kunjungan Singkat, dengan demikian jika mereka masuk atau datang ke wilayah Indonesia harus menggunakan Visa.

Visa Kunjungan Saat Kedatangan/VOA ini diberikan oleh pejabat imigrasi kepada orang asing sesaat setelah mereka tiba di Indonesia di tempat yang telah ditentukan di tempat pemeriksaan imigrasi, visa ini diberikan untuk tujuan wisata, kunjungan sosial budaya, kunjungan usaha bukan bekerja dan kunjungan pemerintah. Pemberian Visa Kunjungan Saat Kedatangan/VOA bagi orang asing yang datang ke Indonesia dilakukan dengan memperhatikan asas manfaat, saling menguntungkan dan tidak menimbulkan gangguan keamanan.

Berdasarkan Asas Resiprocal fasilitas VOA dapat diberikan kepada negara-negara tertentu, seperti: ${ }^{3}$

${ }^{3}$ PerMenHuk.\& HAM RI, No. M.06-IZ.01.10 Tahun 2006. 
1. Afrika Selatan;

2. Amerika Serikat;

3. Argentina;

4. Australia;

5. Austria;

6. Bahrain;

7. Belgia;

8. Belanda;

9. Brasilia;

10. Bulgaria;

11. Cyprus;

12. Denmark;

13. Emirat Arab;

14. Estonia;

15. Finlandia;

16. Hongaria;

17. India;

18. Inggris;

19. Iran;

20. Irlandia;

21. Islandia;

22. Italia;

23. Jepang;

24. Jerman;

25. Kamboja;

26. Kanada;

27. Korea Selatan;

28. Kuwait;

29. Laos;

30. Liechtenstein;

31. Luxemburg;

32. Maladewa;

33. Malta;

34. Meksiko;

35. Mesir;

36. Monaco;

37. Norwegia;

38. Oman;

39. Prancis;

40. Polandia;

41. Portugal; 
42. Qatar;

43. Republik Rakyat China;

44. Rusia;

45. Saudi Arabia;

46. Selandia Baru (New Zealand);

47. Spanyol;

48. Suriname;

49. Swedia;

50. Swiss;

51. Taiwan; dan

52. Yunani.

Visa Kunjungan Saat Kedatangan diberikan oleh pejabat imigrasi yang bertugas di tempat pemeriksaan tertentu, yakni: ${ }^{4}$

1. Pelabuhan udara, diantaranya:

a. Polonia di Medan

b. Sultan Syaif Kasim di Di Pekan Baru

c. Tabing di Padang

d. Soekarno-Hatta di Jakarta

e. Juanda di Surabaya

f. Ngurah Rai di Bali

g. Sam Ratulangi di Manado

2. Pelabuhan laut, diantaranya :

a. Sekupang, Batu Ampar, Nongsa Marina, Teluk Senimba di Batam

b. Bandar Bintan Telani, Lagoi, Bandar Sri Udana, Lobam di Tanjung Uban

c. Sri Bintan Pura di Tanjung Pinang

d. Belawan di Belawan

e. Sibolga di Sibolga

f. Yos Sudarso di Dumai

g. Teluk Bayur di Padang

h. Tanjung Priok di Jakarta

i. Tanjung Emas di Semarang

j. Padang Bai di Bali

k. Jayapura di Jayapura

l. Tenau di Kupang

m. Tanjung Balai Karimun di Tanjung Balai Karimun

n. Soekarno-Hatta di Makasar

\footnotetext{
${ }^{4}$ Kep.Men. Kehakiman \&HAM RI, No.M-04 IZ.01.10 Tahun 2003.
} 
o. Maumere di Nusa Tenggara Timur

p. Bitung di Bitung

q. Pare di Pare

Memperhatikan jumlah negara-negara yang dapat memberikan VOA berdasarkan asas reciprocal atau asas timbal balik dan juga memperhatikan tempat-tempat resmi yang di Indonesia yang dipergunakan untuk melakukan pemeriksaan orang asing oleh pihak imigrasi, maka dapat disimpulkan bahwa tindakan pemberian $V O A$ bagi orang asing di Indonesia dapat dikatakan telah efektif, dan ini berarti merupakan keuntungan bagi pemerintah Indonesia yakni pemasukan kepada Negara berupa Peneimaan Negara Bukan Pajak (PNBP).

Dengan adanya kebijakan Visa On Arrival (VOA) atau Visa Kunjungan Saat Kedatangan bagi orang asing yang masuk ke Indonesia, ini merupakan antisipasi terhadap dampak globalisasi yang menyebar ke setiap aspek kehidupan utamanya dalam aspek mengakomodasikan kepentingan pembangunan nasional ekonomi regional maupun intenasional. Kondisi ini disebabkan oleh karena adanya tuntutan penghapusan hambatan-hambatan yang bersifat tarif maupun non-tarif, sesuai ketentuan GATT/WTO yang sudah diratifikasi oleh pemerintah Indonesia dengan UU No.7 tahun $1994 .^{5}$

\section{B. Tata Cara \& Syarat Pemilikan VOA oleh Orang Asing di Indonesia}

Situasi perkembangan ekonomi global mengharuskan Indonesia semakin terbuka baik di dalam arti fisik maupun non-fisik. Seperti yang diketahui bahwa peran sektor pariwisata makin penting dalam perekonomian Indonesia, baik sebagai salah satu sumber penerimaan devisa maupun kesempatan kerja serta kesempatan untuk berusaha. Dalam rancangan pembangunan nasional untuk meningkatkan kesejahteraan rakyat pengembangan pariwisata harus dilanjutkan dan ditingkatkan dengan memperluas dan memanfaatkan sumber serta potensi pariwisata nasional sehingga menjadi kegiatan ekonomi yang dapat meningkatkan penerimaan devisa, memperluas dan meratakan kesempatan kerja serta kesempatan berusaha khususnya masyarakat

\footnotetext{
${ }^{5}$ Huala Adolf \& A. Chandrawulan, "Masalah-Masalah Hukum Dalam Perdagangan Internasional", (Bandung: Penerbit Alumni, 1994), hal. 13.
} 
sekitar, memperkenalkan alam sekitar, identitas \&kebudayaan bangsa untuk merangsang pembangunan bangsa.

Bagi Indonesia yang memiliki potensi yang sangat besar dalam kepariwisataan diharapkan mampu menjadi salah satu kekuatan pembangunan yang dapat diandalkan, dengan pemasukan devisa yang memadai. Untuk tujuan itu pemerintah berusaha mengeluarkan berbagai kebijakan terpadu untuk memfasilitasi potensi tersebut. Jumlah orang asing dari mancanegara yang datang ke Indonesia setiap tahunnya meningkat baik untuk tujuan wisata maupun kegiatan bisnis.

Arus lalu lintas orang asing yang keluar- masuk Indonesia menyebabkan pemerintah Indonesia berusaha untuk dapat menyeleksi orang asing tersebut sehingga benar-benar mereka yang masuk ke wilayah Indonesia adalah mereka yang dapat memberikan keuntungan bagi kesejahteraan rakyat Indonesia. Oleh karena itu pemerintah Indonesia melalui Keimigrasian memberikan kemudahan fasilitas bagi orang asing untuk dapat masuk ke wilayah Indonesia secara efisien untuk lebih mendukung arus perdagangan, investasi, dan kepariwisataan. Di sisi lain peran keimigrasian dituntut agar proaktif menghapuskan ekses negatif yang timbul dari keberadaan dan kegiatan orang asing untuk mengamankan pembangunan ekonomi.

Kebijakan Keppres No.18 Tahun 2003 mengenai, Bebas Visa Kunjungan Singkat $(B V K S)$ untuk memperlancar arus kunjungan orang asing dengan tujuan meningkatkan arus kunjungan orang asing masuk ke Indonesia baik wisatawan mancanegara maupun para pelaku bisnis guna mendorong pembangunan ekonomi. Sehingga $B V K S$ adalah suatu kebijakan yang diberikan oleh pemerintah Indonesia, dalam hal ini melalui Kantor Imigrasi sebagai kemudahan yang diberikan kepada warga negara asing dari negara-negara tertentu untuk memasuki Indonesia tanpa kewajiban memiliki visa.

Dilihat kenyataan dalam praktek, orang asing yang menggunakan fasilitas $B V K S$ banyak melakukan pelanggaran keimigrasian dan karena kețerbatasan data yang dimiliki sehingga pengawasannya pun sangat minim, hal ini berdampak buruk terhadap negara, karena dapat merugikan negara. Oleh karena itu kebijakan Bebas Visa Kunjungan Singkat dievaluasi dengan dikeluarkan Keputusan Presiden No.18 tahun 2003 tentang Bebas Visa Kunjungan Singkat, dari jumlah 48 negara dikurangi menjadi 9 negara dan 2 wilayah berdasarkan kebijakan pemerintah yaitu berdasarkan politik saringan (selective policy), hanya yang memberikan kemudahan kepada negara-negara memberikan manfaat bagi Indonesia 
Perubahan ini didasarkan pada asas manfaat dimana peraturan ini diberikan kepada negara-negara yang mempunyai sistem kerjasama secara resiprocal (timbal balik) terhadap negara Indonesia. Sedangkan negara-negara yang tidak termasuk dalam kebijakan Bebas VOA/ Visa Kunjungan Saat Kedatangan diberikan kemudahan keimigrasian lainnya, yaitu berupa $V O A$ yang dapat diminta di bandar udara atau pelabuhan laut sesaat setelah mereka tiba di Indonesia.

Dalam pengaturan masuk dan keluar bagi orang asing khususnya mengenai tata cara serta syarat masuk ke Indonesia perihal pelaksanaan pemberian Visa Kunjungan saat Kedatangan atau Visa On Arival( $V O A)$ melalui Imigrasi yaitu:

1. VOA diberikan kepada orang asing warga negara tertentu sebagaimana yang dimaksud dalam keputusan Menteri Kehakiman dan HAM RI No M-04 .IZ.01.10 tahun 2003 tentang $V O A$, yang akan masuk atau datang ke Indonesia dan belum memiliki Visa.

2. Pemberian VOA dilaksanakan di Tempat Pemeriksaan Imigrasi atau tempat-tempat lain yang ditetapkan sesuai dengan Keputusan Menteri Hukum dan HAM RI No. M-04 .IZ.01.10 tahun 2003 tentang $V O A$.

3. Pemberian VOA merupakan kewenangan Direktur Jenderal Imigrasi yang pelaksanaannya dikuasakan kepada Pejabat Imigrasi di Tempat Pemerikaan Immigrasi tertentu.

4. Permohonan memperoleh VOA diajukan langsung oleh yang bersangkutan kepada Pejabat Imigrasi di loket VOA pada Tempat Pemeriksaan Imigrasi, melampirkan persyaratan yang telah ditentukan.

5. Pemohon VOA wajib mengisi kartu kedatangan/keberangkatan yang berfungsi sebagai formulir permohonan.

6. Pemohon $V O A$ membayar bea visa sesuai dengan ketentuan.

7. Melengkapi persyaratan untuk permohonan $V O A$ yakni:

a. Kartu kedatangan/keberangkatan yang telah diisi;

b. Paspor kebangsaan yang sah dan masih berlaku minimal 6 bulan pada saat tiba di Indonesia;

c. Bukti pembayaran biaya visa sesuai dengan ketentuan yang belaku;

d. Tidak termasuk dalam daftar pengkalan.

8. Pemberian VOA dilaksanakan setelah diadakan penelitian kebenaran permohonan, kelengkapan persyaratan dan maksud kedatangannya ke Indonesia. 
9. Pemberian visa dilakukan dengan menerakan tanda pada Paspor kebangsaan yang sah dan berlaku.

10. Pejabat Imigrasi dapat menolak dan atau membatalkan $V O A$ kepada orang asing sesuai dengan kewenangannya.

11. Penolakan pemberian VOA diberitahukan kepada yang bersangkutan dan dilaporkan kepada Direktur Jenderal Imigrasi disertai alasan penolakannya.

Biaya Visa Kunjungan Saat Kedatangan/VOA ditetapkan sesuai dengan ketentuan yang berlaku mengenai tarif atas penerimaan negara bukan pajak yang berlaku pada Departemen Hukum Dan Ham RI. Menurut Keputusan Menteri Kehakiman dan HAM RI No. M.01.IZ.01.10 Tahun 2005 Tentang Perubahan Keempat atas Keputusan Menteri Kehakiman dan Hak Asasi Manusia Republik Indonesia Nomor M-04.IZ.01.10 Tahun 2003 tentang Visa Kunjungan Saat Kedatangan, adapun biaya yang dikenakan adalah sebesar:

1. US $\$ 10$ untuk 7 Hari;

2. US $\$ 25$ untuk 30 Hari.

\section{Peranan $V O A$ Bagi Orang Asing yang Datang ke Indonesia}

Pemberian visa sebagai ijin tertulis serta pengaruhnya bagi orang asing yang masuk ke wilayah Indonesia, sejalan dengan pertumbuhan dan perkembangan perekonomian global, yang berimplementasi dengan semakin banyak pula manusia yang mengadakan perjalanan darat, laut maupun udara dalam berbagai kepentingan baik dalam tingkat domestik maupun internasioanal. Akibat mobilitas manusia menunjukkan peningkatan yang cukup besar, namun hal ini tidak berarti aspek lain dalam halnya ideologi, politik, sosial budaya dan keamanan tidak berpengaruh pada mobilitas manusia namun kecenderungan perkembangan dunia saat ini lebih terarah pada aspek perekonomian.

Pasal 1 Ayat (2) UU No.9 Tahun 1992 tentang keimigrasian, menyatakan bahwa wilayah Negara Republik Indonesia adalah seluruh wilayah Negara Republik Indonesia yang meliputi: wilayah darat, laut dan udara, yang sering dikenal juga dengan sebutan Wilayah Indonesia. Selanjutnya dalam hubungan internasional, seseorang yang melakukan kegiatan lintas negara atau melakukan pelintasan antar negara memerlukan dokumen yang disebut Paspor. Secara harfiah Paspor merupakan surat perjalanan yaitu sebagai dokumen resmi yang dikeluarkan oleh pejabat berwenang dari suatu Negara yang memuat 
identitas diri pemegang paspor, dan berlaku untuk melakukan perjalalanan antar Negara (Pasal 1 Ayat (3) UU No 9 Tahun 1992). Paspor dalam makna harfiah lain, sebagai melewati pelabuhan, yang memuat identitas diri pemegang paspor dan negara yang mengeluarkan paspor serta menunjukkan identitas Kewarganegaraan pemegang papor. Dalam arti yang lain Paspor juga memiliki pengertian sebagai ijin tertulis bagi pemegang paspor untuk dapat memasuki wilayah suatu Negara berdaulat lain dalam masyarakat internasional dan sekaligus Paspor juga bermakna sebagai pelindung secara yuridis bagi seseorang yang melakukan perjalanan atau kegiatan bisnis yang melewati lintas batas Negara atau perjalanan/kegiatan yang bersifat internasional.

Dalam hal melakukan perjalanan lintas antar negara, bahwa masing- masing negera tersebut memiliki suatu kedaulatan, bagi setiap orang asing yang hendak masuk dalam suatu wilayah Negara lain disamping harus memiliki dokumen Paspor, juga diperlukan dokumen berupa $V i s a$. Visa diperlukan guna proses penyeleksian terhadap orang asing yang masuk dan melakukan perjalanan ke wilayah antar negara. Pemeriksaan Paspor dan Visa yang tercantum di dalamnya merupakan bagian atas proses pemeriksaan keimigrasian pada saat kedatangan maupun keberangkatan orang asing di suatu negara (seperti di Indonesia).

Di Indonesia, dalam proses pemeriksaan keimigrasian memiliki suatu dasar berupa kebijakan sesuai dengan kepentingan nasional Indonesia yang bersifat selektif (selektive policy), sehingga pengawasan terhadap orang asing oleh pihak Imigrasi memiliki dua unsur penting yaitu:

1. Pengaturan tentang berbagai hal mengenai lalu lintas orang keluar masuk dan tinggal dari dan ke wilyah negara Republik Indonesia;

2. Pengaturan tantang bebagai hal mengenai pengawasan orang asing di wilayah negara Republik Indonesia.

Berdasarkan hukum internasional pengaturan lalu lintas keluar masuk wilayah indonesia merupakan hak dan wewenang suatu negara serta merupakan salah satu perwujudan dan kedaulatan sebagai negara hokum yang berdasarkan Pancasila dan UUD 1945. Dalam UU No.9 tahun 1992 pengaturan lalu lintas masuk dan keluar wilayah Indonesia ditetapkan harus melewati Tempat Pemeriksaan Imigrasi (TPI) yaitu, di pelabuhan laut, bandar udara atau tempat-tempat lain yang ditetapkan oleh Menteri sebagai tempat masuk dan keluar dari wilayah Indonesia. 
Pelanggaran atas ketentuan ini dikategorikan sebagai tindakan memasuki wilayah Indonesia secara tidak sah, artinya setiap tindakan keluar masuk wilayah Indonesia yang tidak melalui Tempat Pemeriksaan Imgrasi atau melalui tempat pemeriksaan imigrasi seperti melalui tempat-tempat yang tidak ditentukan secara resmi oleh pemerintah atau Imigrasi. Selanjutnya tindakan secara tidak sah ini dapat dikenakan sanksi pidana sesuai dengan UU Keimigrasian yang berlaku di Indonesia. Setiap orang asing yang keluar masuk wilayah Indonesia harus memiliki paspor sebagai dokumen perjalanan dan identitas pemegang serta kewarganegaraannya juga harus memiliki visa yang merupakan ijin tertulis yang dikeluarkan pejabat berwenang yang memuat persetujuan bagi orang asing yang akan masuk dan melakukan perjalanan ke wilayah Indonesia.

Visa Kunjungan Saat Kedatangan/VOA ini diberikan dengan memperhatikan kepentingan negara dimana hanya diberikan kepada negara yang benar-benar dapat menguntungkan dan memberikan manfaat bagi pembangunan Indonesia. Sesuai dengan asas manfaat dan resiprokal antara kedua negara dimana kebijakan antara keduanya saling menguntungkan.

Kebijakan Visa Kunjungan Saat Kedatangan/VOA oleh Pemerintah RI mulai diberlakukan sejak tanggal 1 Pebruari 2004 dan kenyataannya dapat berjalan dengan lancar, selanjutnya pemerintah RI berusaha memperhatikan pengaruh positif yang timbul akibat pemberian $V O A$ terhadap orang asing yang datang ke Indonesia.

Berdasarkan data pada Pelabuhan udara/laut di seluruh Indonesia, yang diperoleh melalui bandara Soekarno-Hatta Jakarta, bulan April hingga Juli 2005 terdapat indikasi arus orang asing yang masuk ke Indonesia tiap bulan terjadi peningkatan sejumlah tiga (3) ribu - lima (5) ribu orang, dan dari jumlah kedatangan orang asing ke Indonesia itu yang menggunakan Visa On Arrival (VOA) terjadi kenaikan setiap bulan yaitu berkisar dari empat (4) ribu - lima (5) ribu Visa On Arrival (VOA). ${ }^{6} \mathrm{Hal}$ ini menunjukkan bahwa kebijakan Visa On Arrival (VOA) mendapat sambutan yang cukup baik dari orang asing yang datang ke Indonesia yang merupakan subyek dari $V O A$.

Hal ini dimungkinkan karena dengan adanya $V O A$ yang diberikan sesaat setelah orang asing datang kemudian dapat langsung menuju tempat pemberian VOA berupa loket (counter), bagi mereka yang

6 Anandita, Dwi Hari Wibowo, "Efektivitas Pemberian Visa Kunjungan Saat Kedatangan Bagi Orang Asing Di Indonesia", Hasil Penelitian Ilmiah (Skripsi), Fak.Hukum Univ.Warmadewa Denpasar, 2006: Lampiran. 
negaranya merupakan subyek $V O A$. Hal ini memudahkan orang asing untuk mendapatkan visa karena membutuhkan waktu kurang lebih dua sampai lima menit, dimana hanya memberikan persyaratan yang telah ditentukan lalu memohon visa sesuai sesuai dengan maksud dan jangka waktu kunjungan kemudian dapat memasuki wilayah Indonesia setelah melalui proses pemeriksaan Imigrasi pada Tempat Pemeriksaan Imigrasi.

Kemudahan VOA memberikan keuntungan bagi orang asing yang datang dengan maksud untuk melakukan perjalanan wisata, dan kegiatan bisnis, atau hanya untuk transit/lewat, dll di Indonesia, karena proses untuk memohon Visa sebagai ijin masuk ke Indonesia diperoleh cepat dan mudah tanpa harus menuggu lama sehingga tidak mengganggu kegiatan bisnis orang asing tersebut.

Visa On Arrival (VOA) ini diberikan pada dasarnya untuk memberikan kemudahan kepada orang asing yang masuk ke Indonesia agar mereka tidak perlu lagi untuk memohon Visa pada Kedutaan Besar RI atau pada kantor perwakilan RI dan juga agar terciptanya suatu efektivitas dan efesiensi dalam pelayanan Keimigrasian dengan tidak mengesampingkan faktor keamanan dan manfaat dari negaranegara yang diberikan kemudahan keimigrasian dalam hal VOA.

\section{Penutup}

\section{A. Simpulan}

Peranan Visa On Arrival (VOA) atau Visa Kunjungan saat Kedatangan bagi orang asing di Indonesia adalah merupakan ijin tertulis, sebagai kemudahan bagi orang asing yang masuk/datang ke Indonesia, oleh karena VOA dapat diperoleh melalui Pelabuhan Udara/laut, seperti di Bandara-Soetta Jakarta, Bandara Ngurah Rai Denpasar-Bali, dll pada saat kedatangan orang asing tersebut di Indonesia dan tidak lagi melalui perwakilan RI di Luar Negeri yang dianggap sulit dan waktu lama untuk memperoleh Visa.

\section{B. Saran}

Mengingat peran $V O A$ bagi orang asing yang datang ke Indonesia demikian urgent, maka dapat dibuat saran sebagai berikut:

1. Agar pihak Imigrasi secepat mungkin merealisasikan pembentukan network dalam suatu sistem informasi dan 
manajemen secara online didsamping juga membuat kerja sama bilateral/multilateral dengan negara lain dalam hubunan Internasional;

2. Agar pihak imigrasi merealisasikan pembukaan pintu masuk secara selektif untuk mengantisipasi pertumbuhan perekonomian regional maupun internasional;

3. Bentuk dan format Visa sebaiknya dibuat diperkecil dengan tidak mengurangi pengamanan dalam stiker $V O A /$ Visa Kunjungan Saat Kedatangan;

4. Visa Kunjungan Saat Kedatangan (VOA) perlu diisi kode atau indeks yang menunjukkan tujuan orang asing melakukan kunjungan ke Indonesia untuk memudahkan pengawasan oleh Imigrasi pada saat dilakukan pemeriksaan. 


\section{Daftar Pustaka}

Adolf, Huala \& A.Chandrawulan. Masalah-Masalah Hukum Dalam Perdagangan Internasional, Bandung: Penerbit Alumni, 1993.

Anandita, Dwi Hari Wibowo. 2006, Efektivitas Pemberian Visa Kunjungan Saat Kedatangan Bagi Orang Asing Di Indonesia, Hasil Penelitian Ilmiah (Skripsi), Fakultas Hukum Univ. Warmadewa, Denpasar.

Departemen Hukum dan Hak Azasi Manusia, Peraturan Menteri Hukum Dan Hak Azasi Manusia Nomor M.06- IZ.01.10 Tahun 2006 tentang Perubahan atas Keputusan Menteri Kehakiman \& HAM Nomor M04.IZ.01.10 Tahun 2003 tentang Visa On Arrival (VOA).

- Keputusan Menteri Kehakiman Nomor M-04.IZ.01.10 Tahun 2003 Tanggal 31 Desember 2003 tentang VOA atau Visa Kunjungan Saat Kedatangan.

Republik Indonesia, Undang-Undang Nomor 9 Tahun 1992 tentang Keimigrasian.

- Undang-Undang Nomor 62 Tahun 1958 tentang Kewarganegaraan.

- Undang-Undang Nomor 12 Tahun 2006 tentang Kewarganegaraan.

. Peraturan Pemerintah Nomor 32 Tahun 1994 tentang Visa, Izin Masuk Dan Izin Keimigrasian.

. Keputusan Presiden (Keppres), Nomor 18 Tahun 2003 tentang Bebas Visa Kunjungan Singkat (BVKS).

Ronny, Hanitijo Soemitro. Metodologi Penelitian Hukum, Cetakan Pertama, Jakarta: Ghalia Indonesia, 1983.

Santoso, Imam M. Perspektif Imigrasi Dalam Pembangunan Ekonomi Dan Ketahanan Nasional, Jakarta: Universitas Indonesia, 2004. 